\title{
KONSEP OTONOMI DAERAH DALAM HUKUM TATA NEGARA ISLAM
}

\author{
Weni Gusdi Sari' ${ }^{1}$, Zainuddin² \\ 1Institut Agama Islam Negeri Batusangkar \\ e-mail: wenitkj3@gmail.com \\ 2 Institut Agama Islam Negeri Batusangkar \\ e-mail: zainuddin@iainbatusangkar.ac.id
}

\begin{abstract}
This study examines the concept of regional autonomy in Islamic constitutional law about how is the concept of regional autonomy in Islamic State Constitutional Law and how is the autonomy of regional beads in the perspective of Islamic constitutional law. This research is a qualitative research library (Library Research). The data of this study were obtained through the Islamic law/Fiqh research method with a historical approach. After the data has been collected, it is then processed by studying, researching, studying and understanding the concept of regional autonomy in Islamic Constitutional Law referring to the Al-Quran and Hadith and related articels. This study found the following results: (1) The concept of regional autonomy in Islamic constitutional law is practiced in three types of regional government, namely al-imarah al-khashah, al-imarah al-ammah, al-imarah al-istila. (2) The autonomy of the regional head's power in the perspective of fiqh siyasah dusturiyah or Islamic constitutional law is in accordance with the conditions and authority granted by a Khalifah. The Khalifah as head of state gives authority to al-Amir (Head of Region) in the functions of: collecting taxes in the region, managing regional administration and providing services to the people in the region, maintaining security in the region, attracting kharaj and collecting rakat, upholding and disseminating Islam in the region. area, as well as being a prayer priest.
\end{abstract}

Keywords : Regional Autonomy, Islamic Constitutional Law, Local Leader

\section{PENDAHULUAN}

Konfigurasi masyarakat muslim yang pernah dibangun oleh Rasulullah SAW bersama para sahabatnya di Madinah, yang layak disebut sebagai negara Islam, telah menjadi contoh kebenaran yang menduduki posisi tertinggi setelah Al-Quran (Islam, 2002: 1). Di negara ini Nabi Muhammad SAW bertindak sebagai pemimpin umat Islam dengan Piagam Madinah sebagai konstitusi.

Negara Islam Madinah secara periodik terdiri dari dua masa. Pertama, masa pemerintahan Nubuwwah yang langsung dipimpin oleh Rasulullah dengan bimbingan Allah SWT. Kedua, masa pemerintahan Khalifah Rasyidah yang dipimpin oleh manusia biasa, yang bukan Nabi, tetapi mereka merupakan murid-murid pertama Rasulullah SAW yang tidak lagi menerima wahyu karena wahyu telah disempurnakan oleh Allah SWT menjelang beliau wafat, dan wahyu yang telah diturunkan itu telah dihafalkan oleh mereka. Konfigurasi otonomi pemerintahan yang dibangun oleh Nabi Muhammad SAW menjadi kaidah metodologis yang harus diikuti oleh setiap generasi penerus masyarakat muslim bila hendak membangun kembali negara Islam transendental (Islam, 2002: 2).

Selanjutnya yang dimaksud dengan otonomi daerah adalah merupakan pelimpahan wewenang dari pemerintah pusat ke pemerintah daerah untuk mengatur sendiri daerahnya. Pengertian otonomi daerah secara umum, yakni ada kewenangan yang melekat pada sesuatu organisasi atau unit dalam organisasi, untuk mengembangkan fungsi-fungsi tertentu. Menurut Kamus Besar Bahasa Indonesia (KBBI) otonomi daerah 
adalah hak, wewenang, dan kewajiban daerah untuk mengatur dan mengurus rumah tangganya sendiri sesuai dengan peraturan perundang-undangan yang berlaku.

Dalam konteks pemerintahan, otonomi biasanya dilihat dari tiga dimensi. Pertama, otonomi negara dalam berhubungan yang ada dalam masyarakat (terutama masyarakat ekonomi dan partai politik). Kedua, otonomi pemerintahan daerah dalam hubungan dengan pemerintah pusat. Ketiga, otonomi unit-unit bawahan dalam organisasi pemerintahan hubungan dengan unit yang lebih tinggi (Worotikan, 1995: 30-31).

Otonomi daerah merupakan wacana yang hangat dibicarakan, karena ini menyangkut bagaimana menyejahterakan rakyat di suatu negara. Otonomi daerah dipandang sebagai sistem yang memungkinkan daerah memiliki kemampuan untuk mengoptimalkan potensi terbaik yang dimiliki daerah dan mendorong daerah untuk berkembang sesuai dengan kerakteristik ekonomi, geografis dan sosial budaya di daerah yang bersangkutan (Hos, 2005: 19).

Fiqh siyasah merupakan salah satu aspek hukum Islam yang membicarakan pengaturan dan pengurusan kehidupan manusia dalam bernegara demi mencapai kemaslahatan bagi manusia itu sendiri. Fiqh siyasah membicarakan tentang siapa sumber kekuasaan, siapa pelaksana kekuasaan, apa dasar kekuasaan dan bagaimana cara-cara pelaksana penguasa menjalankan kekuasaan yang diberikan kepadanya, dan kepada siapa pelaksana kekuasaan mempertanggungjawabkan kekuasaannya (Iqbal, 2016: 4-5). Di bagian fiqh siyasah yang membahas bidang ini adalah fiqh siyasah dusturiyah. Fiqh siyasah dusturiyah adalah bagian fiqh siyasah yang membahas masalah perundangundangan negara. Di samping itu, kajian ini juga membahas konsep negara hukum dalam siyasah dan hubungan timbal balik antara pemerintah dan warga negara serta hak-hak warga negara yang wajib dilindungi (Iqbal, 2016: 177).

Dalam dimensi hukum tata negara, istilah "pemerintah" masih identik dengan golongan eksekutif yang terdiri dari presiden, menteri-menteri hingga kepala desa. Sementara ilmu hukum administrasi negara memandang pemerintah memiliki dimensi yang lebih luas meliputi lembaga-lembaga unsur trias politika yaitu lembaga legislatif, eksekutif, dan yudikatif. Lembaga legislatif mempunyai wewenang membuat undangundang, lembaga eksekutif mempunyai wewenang menerapkan undang-undang atau melaksanakan undang- undang, dan yudikatif mempunyai wewenang mempertahankan pelaksanaan undang-undang (Islam, 2002: 16). Dalam sistem pemerintahan Islam ada tiga kekuasaan yang menjalankan negara. Ketiga kekuasaan itu adalah lembaga legislatif disebut dengan al-sulthah al-tasyiri'iyah, lembaga eksekutif disebut dengan al-sulthah altanfidziyah dan lembaga yudikatif disebut dengan al-sulthah al-qadhaiyah (Iqbal, 2016: 157).

Penulis fokus mengkaji al-sulthah al-tanfidziyah. Lembaga eksekutif atau al-sulthah al-tanfidziyah bermakna bahwa disini negara memiliki kewenangan untuk menjabarkan dan mengaktualisasikan perundang-undangan yang telah dirumuskan tersebut. Dalam hal ini, negara melakukan kebijaksanaan baik yang berhubungan dengan dalam negeri, maupun yang menyangkut dengan hubungan dengan negara lain (hubungan internasional). Pelaksana tertinggi kekuasaan ini adalah pemerintah (kepala negara) dibantu oleh para pembantunya (kabinet atau dewan menteri) yang dibentuk sesuai dengan kebutuhan dan tuntutan situasi yang berbeda antara suatu negara dengan negara 
Islam lainnya (Iqbal, 2016: 158).

Sistem kepemimpinan dalam Islam disebut dengan khilafah dan orang yang memimpinya disebut Khalifah sebagai kepala negara, dapat juga disebut dengan Imam atau Amirul Mukmin. Pemimpin daerah dalam Islam disebut dengan al-amir dengan pemerintahannya disebut imarah. Para pemimpin mempunyai wewenang untuk membuat kebijakan yang mengatur dan yang dibutuhkan di lingkungan masyarakatnya. Sejauh mana kewenangan tersebut dimiliki oleh pemimpin daerah, tentu hal ini memerlukan pengkajian lebih dalam.

Pemimpin adalah orang yang diberi amanat oleh Allah SWT, untuk memimpin rakyatnya, dan akan diminta pertanggungjawabannya oleh Allah SWT (Rusdi, 2002: 146). Masyarakat wajib mematuhi kebijakan yang dibuat oleh pemimpin selagi tidak bertentangan dengan aturan Allah SWT. Sebagaimana dalam firman Allah dalam surat An-Nisa ayat 59. Adapun yang menjadi tujuan dan tugas pemimpinan (Khalifah, Imamah, Amir) adalah sebagai berikut:

a. Iqamatudin (menegakkan agama), maksudnya adalah menjadikan agama sebagai syiar nyata sebagaimana yang diperintahkan seperti ikhlas dalam menjalankan ketaatan, menghidupkan As-Sunnah dan mematikan bid"eah agar seluruh hamba melaksanakan ketaatan kepada Allah.

b. Menata dunia dengan agama atau mengatur semua persoalan kehidupan dengan hukum yang ditentukan Allah. Maksudnya adalah menata dan mengatur seluruh persoalan hidup sesuai kaidah, prinsip, dan hukum-hukum syariat yang tertera secara nash atau disimpulkan dari nash-nash yang ada sesuai kaidah ijtihad yang tepat (Abdullah, 2016: 40).

Dalam sejarah, ketatanegaraan Islam dipraktekkan sejak zaman Rasulullah SAW sampai dengan al-Khulafa al-Rasyidin sebagai negara kesatuan. Namun untuk saat ini, belum ditemukan kajian sejauh mana konsep otonomi daerah tersebut dipraktikkan pada negara Islam. Oleh karena itu, dalam kajian ini akan dibahas tentang bagaimana konsep otonomi daerah dalam hukum tata negara Islam dan bagaimana otonomi kekuasaan kepala daerah dalam perspektif hukum tata negara Islam.

\section{METODE PENELITIAN}

Jenis penelitian yang digunakan merupakan penelitian kepustakaan (Library Research) yang bersifat kualitatif dengan metode penelitian hukumIslam/Fiqh dengan pendekatan historis. Penelitian ini berusaha mengkaji, meneliti, menelaah dan memahami konsep otonomi daerah dalam hukum tatanegara islam merujuk kepada alquran dan hadist serta karya tulis yang terkait. Bahan data primer dalam penelitian ini adalah buku fikih siyasah, fikih dusturiyah, sejarah Islam. Kemudian bahan data sekunder penelitian ini adalah artikel dalam jurnal. Selanjutnya dalil hukum utama dalam penelitian ini adalah al-quran dan hadits.

\section{PEMBAHASAN}

\section{A. Konsep Otonomi Daerah dalam Hukum Tata Negara Islam}


Negara Madinah merupakan negara Islam yang dibangun oleh Nabi Muhammad dan para sahabatnya. Negara Madinah ini sudah memenuhi syarat-syarat pokok berdirinya suatu negara yaitu adanya wilayah, rakyat, pemerintahan dan undang-undang dasar. Nabi Muhammad SAW bertindak sebagai kepala negara dan Piagam Madinah sebagai konstitusinya (Iqbal, 2016: 37). Dalam sejarah ketatanegaraan Nabi Muhammad SAW, sistem pemerintahannya dapat dikatakan demokratis, beliau mengadakan pedelegasian dan pembagian kekuasaan kepada para sahabaT dalam rangka memperlancar tugas-tugas negara. Nabi Muhammad SAW dibantu oleh beberapa sekretaris, salah satu nama sekretaris yang terkenal adalah Zaid Ibn Tsabit. Dalam mengadili pelanggaran ketertiban umum, saat itu lembaga hisbah belum terbentuk menjadi sebuah lembaga, yang ada hanyalah praktek-praktek penegakan al-amru bi alma'ruf wa nahyu an al-munkar (perintah menegakkan yang benar dan melarang yang salah) yang dilakukan sendiri oleh Nabi Muhammad. (Abdullah, 2015: 36).

Untuk pemerintahan di daerah, beliau mengangkat beberapa sahabat sebagai gubernur dan hakim. Ada 10 daerah yang berpusat pada Madinah pada masa nabi ini, berikut nama-nama daerahnya beserta gubernurnya :

1. Wilayah Akhmus, kepala daerah wilayah ini adalah Ali Bin Abi Thalib.

2. Wilayah Oman, kepala daerah wilayah ini adalah Amru Bin 'Ash.

3. Wilayah Yaman, kepala daerah wilayah ini adalah Bazan Bin Sassan, setelah beliau meninggal digantikan oleh putranya yang bernama Syahar Bin Bazan, kemudian digantikan oleh Khalid Bin Said.

4. Wilayah Kindah dan Sadaf, kepala daerah wilayah ini adalah Muhajir Bin Umayyah.

5. Wilayah Hadramaut, kepala daerah wilayah ini adalah Ziad Bin Lubaid.

6. Wilayah Zubaid dan Aden, kepala daerah wilayah ini adalah AbuMusa Asy'ari.

7. Wilayah Jundi, kepala daerah wilayah ini adalah Mu'az Bin Jabal.

8. Wilayah Najran, kepala daerah wilayah ini adalah Abu Sufyan BinHarb.

9. Wilayah Taima, kepala daerah wilayah ini adalah Yazid Bin Abi Sufyan.

10. Wilayah Kotapraja Mekah, kepala wilayah daerah ini adalah Attab Bin Asid (Ahmad, $2001:$ 180)

Dari sejarah ketatanegaraan nabi ini, sudah mulai ada pembagian kekuasaan kepada pemerintah daerah yaitu ditandai dengan nabi mengangkat beberapa sahabat menjadi gubernur dan hakim. Selanjutnya penulis akan membahas ketatanegaraan khulafaurasyidin yang dimulai dengan Khalifah Abu Bakar Al-Shiddiq. Setelah terpilih menjadi Khalifah, Abu Bakar menyampaikan pidato kenegaraannya di Masjid Nabawi yang berbunyi :

"Wahai manusia, sesungguhnya aku telah kalian percayakan untuk memangku jabatan khalifah, padahal aku bukanlah orang yang paling baik di antara kalian. Kalau aku menjalankan tugasku dengan baik, bantulah aku. Sebaliknya, aku salah, luruskanlah langkahku. Kebenaran adalah kepercayaan dan dusta adalah penghianatan. Orang yang lemah di kalangan kamu adalah kuat dalam pandanganku, sesudah hak-haknya aku berikan kepadanya. Sebaliknya,orang yangkuat di antara kalian aku anggap lemah setelah haknya saya ambil. Bila ada yang meninggalkan perjuangan dijalan Allah, maka Allahakan menghinakannya. Bila kejahatan itu sudah meluas pada suatu golongan, maka Allah akan menyebarkan bencana kepada mereka. Taatilah aku selama aku taat kepada Allah dan Rasul-nya. Tapi selama saya tidak taat pada Allah dan Rasul-nya, gugurlah kesetian kalian kepadaku. Laksanakanlah shalat, Allah akan memberikanmu rahmat" 
(Fatmawati, 2010: 112).

Ada 5 poin penting dari pidato Abu Bakar ini yaitu pertama, pelantikan Abu Bakar ini dapat dikatakan kontrak sosial antara pemimpin dan rakyatnya. Kedua, Abu Bakar meminta rakyatnya untuk berpartisipasi untuk mengawasi dirinya. Ketiga, tekad Abu Bakar untuk menegakkan keadilan dan HAM. Keempat, seruan untuk membela negara (jihad) pada saat dibutuhkan. Kelima, perintah untuk menjalankan shalat (Iqbal, 2016: 53).

Sistem pemerintahan pada Khalifah Abu Bakar ini menekankan prinsip pembagian kekuasaan dan penempatan orang sesuai dengan kemampuan. Untuk pelaksanaan tugas eksekutif, memberikan kekuasaannya ke sahabat senior yaitu Ali, Usman, dan Zaid Ibn Tsabit sebagai sekretaris negara yang berkedudukan di Madinah. Untuk keuangannegara, beliau menunjuk Abu Ubaidah sebagai bendahara, dan untuk hakim agung diserahkan kepada Umar Ibn Al-Khaththab. Majelis syura yang dibentuk Abu Bakar yang terdiri dari Umar, Usman Abd Al-Rahman Ibn Awf, Muadz Ibn Jabal, Ubay Ibn Ka'ab dan Zaid Ibn Tsabit, dimasa Khalifah inilah Al-quran dibukukan (Iqbal, 2016: 58).

Kemudian untuk tugas-tugas di daerah, beliau meneruskan pola Nabi Muhammad SAW mengangkat gubernur-gubernur. Mereka bertanggung jawab kepada Khalifah dan diberikan keleluasaan untuk mengangkat stafnya tetapi memiliki otoritas dan otonomi terbatas. Berikut 8 nama gubernur dan daerah yang dipimpinnya sebagai berikut:

1. 'Utab Ibn Asid diangkat untuk Mekkah.

2. 'Usman Ibn Abi Al-'Ash diangkat untuk Tha'if.

3. Muhajir Ibn Umaiyah diangkat untuk Shan'a.

4. Zaid Ibn Labid diangkat untuk Hadramaut.

5. Ya'la Ibn Umaiyah diangkat untuk Khaulan.

6. 'lla Ibn Tsur Al-Hadrami untuk Zabid dan Rima.

7. Mu'adz Ibn Jabal diangkat untuk Janad.

8. 'Abdullah Ibn Tsur diangkat untuk Jarsy. (Iqbal, 2016: 59)

Dari sejarah ketatanegaraan Abu Bakar yang meneruskan kebijakan Nabi Muhammad SAW dengan mengangkat gubernur untuk memimpin pemerintahan di daerah, sudah terlihat bahwa para gubernur ini memiliki otoritas dan otonomi terbatas. Hal ini pun menunjukkan bahwa Abu Bakar sudah membagi kekuasaan legislatif, eksekutif dan yudikatif meskipun belum secara tegas memisahkannya. Serta telah berhasil membangun pemerintahan yang bersih, etis, serta mengikutsertakan partisipasi segenap warganya. Kekuasaan Abu Bakar ini sangat egaliter dan demokratis dan menerapkan pola pemerintah yang modern pada masa itu. (Iqbal, 2016: 60).

Selanjutnya, dari sejarah ketatanegaraan Khalifah Umar Ibn Al-Khathab hal yang terkenal adalah sebagai pembangun utama pemerintahan daerah otonomi dan merupakan demokrat terbesar, beliau telah mewujudkan ulil al-amri yang diajarkan Islam dalam pemerintahan daerah otonomi yang memiliki hak- hak penuh untuk mengatur daerahnya serta daerah diberi hak melaksanakan peraturan dan instruksi dari pemerintah pusat. Prinsip musyawarah juga diwujudkan pada Khalifah Umar ini (Esha, 2011: 91). Pada sejarah ketatanegaraan Khalifah Usman, point yang dapat dikenal adalah adanya sistem nepotisme. Usman hanya sebagai boneka menjadi Khalifah, yang mengendalikannya adalah keluarga besarnya sehingga Usman meninggal di tangan umat Islam sendiri. Pejabat-pejabat termasuk pergantian gubernur-gubernur di daerah yang diangkat Usman 
tidak menjalankan tugasnya dengan baik, sehingga terjadilah kekacauan (Fatmawati, 2010: 156). Dari sejarah ketatanegaraan Khalifah Ali, penulis melihat untuk pemerintahan daerahnya mengikuti pemerintahan Khalifah sebelumnya dan berusaha memperbaiki keadaan yang kacau akibat pengangkatan gubernur-gubernur yang diangkat Khalifah Usman dari keluarganya.

Hal ini dapat disimpulkan bahwa sistem pemerintah yang dibangun oleh Nabi Muhammad SAW dijadikan sebagai embrio dari sebuah pemerintahan. Sistem administrasi pada saat itu belum begitu kompleks akibat perkembangan wilayah Islam bagan organisasi dan administrasi.

\section{Konsep Otonomi Daerah}

Fakta sejarah yang mengambarkan konsep otonomi daerah di negara Islam dapat dilihat dari sejarah ketatanegaraan Nabi Muhammad SAW yang sudah penulis jabarkan sebelumnya yaitu Nabi Muhammad SAW dibantu para sahabat dalam mejalankan tugas negara, sudah ada gubernur dan hakim untuk melaksanakan tugas di daerah. Kemudian, di al-khulafau al-rasyidin sampai selanjutnya, pelaksanaan pemerintahan daerah sudah semakin berkembang terutama di masa pemerintahan Umar Ibn Khattab. Di masa pemerintahan beliaulah yang memberikan otoritas pemerintahan daerah yang luas. Salah satu hadits yang memperkuat dan menjadi bukti adanya konsep otonomi daerah ini dalam negara Islam adalah hadist nabi mengenai penunjukan Mu'adz Ibn Jabal menjadi hakim di daerah. Setelah Nabi Muhammad SAW wafat, umat muslim dianjurkan untuk mentaati pemimpin setelahnya. Asas-asas sebagai pelaksana otonomi daerah. Dilihat dari sejarah ketatanegaraan Nabi Muhammad SAW sampai dengan al-khulafahu al-rasyidin dapat dikatakan mengandung asas desentralisasi, asas dekonsentrasi dan asas pembantuan. Pemerintahan pusat (Khalifah) memberikan pelimpahan kekuasaan bidang tertentu secara vertikal kepada pemerintahan daerah (gubernur) dimana para gubernur bertanggung jawab kepada Khalifah.

\section{Prinsip-Prinsip Pemberian Otonomi Daerah}

Prinsip-prinsip pemberian otonomi daerah dalam sejarah ketatanegaraan Nabi Muhammad SAW sampai dengan al-khulafau al-rasyidin sudah menggambarkan adanya prinsip otonomi luas, prinsip otonomi nyata serta prinsip otonomi yang bertanggung jawab. Menurut Saiful Islam dalam buku yang berjudul "Prinsip-Prinsip Otonomi Daerah Dalam Pemerintahan Negara Islam", kepemimpinan Nabi Muhammad dibantu para sahabat selama 10 tahun berlangsung prinsip-prinsip otonomi dalam pemerintahan Negara Islam pertama di Madinah diekplorasi ke dalam 3 prinsip otonomi yaitu :

\section{a. Prinsip-Prinsip Otonomi Akidah}

Prinsip ini terdapat dalam surat Ali Imran yang meliputi seperti pengakuan keesaan Allah, nubuwwah, kebenaran Al-Quran, meluruskan pemikiran negatif yang bersumber dari anggota masyarakat ahli kitab seperti Nasrani dan Yahudi sebagai bagian dari keseluruhan anggota masyarakat

\section{b. Prinsip Otonomi Syariah}

Prinsip ini meliputi ketentuan-ketentuan seperti dibidang haji, jihad, zakat.

\section{c. Prinsip Otonomi Ihsan}

Prinsip ini terdapat dalam surat An-Nisa meliputi amanat, keadilandan taat. Prinsip otonomi ihsan ini dalam membangun komunitas keluarga dan masyarakat luas di atas 
dasar takaful (saling tanggung jawab), tarahum (sayang-menyayangi), tanashuh dan tasamuh (saling menasehati dan pengertian/toleransi), amanat dan adil menuju terwujudnya struktur masyarakat yang kuat. (Saiful Islam, 2002:37-38).

\section{Tujuan Otonomi Daerah}

Tujuan otonomi daerah dalam sejarah ketatanegaraan negara Islam juga meningkatkan pelayanan kepada rakyat di daerah dan mensejahterakan rakyat yang ada di daerah. Kemudian ada 2 yang menjadi tujuan dari pemerintah dalam pelaksanaan otonomi di daerah dalam negara Islam sebagai berikut :

a. Iqamatudin (menegakkan agama). Menegakkan agama merupakan tujuan yang harus ditegakkan oleh pemerintah daerah, karena agama ini menjadi kunci dari kokohnya imam seseorang yang sangat berpengaruh dalam menjalankan roda pemerintahan yang ada di daerah.

b. Menata dunia dengan agama atau mengatur persoalan kehidupan dengan hukum yang ditentukan Allah SWT. Mengatur persoalan dengan hukum yang ditentukan Allah merupakan hal yang harus dilakukan pemerintah daerah dalam menjalankan tugasnya sebagai pemimpin yang bisa mewujudkan kesejahteraan rakyat, mengatur roda pemerintahan dengan sabaik- baiknya, mampu berprilaku adil memimpin rakyatnya dan memberipelayanan yang baik (Abdullah, 2016: 40)

\section{B. Otonomi Kekuasaan Kepala Daerah Dalam Hukum Tata Negara Islam}

Kekuasaan tertinggi di dalam sejarah ketatanegaraan Islam berada di tangan Khalifah. Khalifah inilah yang menjadi penguasa tertinggi dalam mengatur segala urusan pemerintahan yang meliputi kewenangan dalampemerintahan (Ibnu dan Zana, 2008: 308). Berdasarkan akad inabah (akad untuk mewakilkan) Khalifah memberikan wewenang kepada gubernur untuk mewakilkan tugas memimpin di daerah dengan mempertanggung jawabkan tugasnya kepada pemerintah pusat (Khalifah) (Supriyadi, 2007: 229). Jadi, otonomi kekuasaan kepala daerah diberi kewenangan oleh pemerintahan pusat kepada pemerintahan di daerah untuk mengatur daerah yang di pimpinnya dengan pengawasan dari pusat/Khalifah.

Sebutan kepala daerah di zaman Nabi Muhammad SAW dan Al- Khulafau AlRasyidin terkenal dengan sebutan istilah Amir. Pada zaman Nabi Muhammad tugas utama Amir pada mulanya yaitu pengelolaadministrasi politik, pengumpulan pajak dan sebagai pemimpin agama. Setelah masa pemerintahan Nabi, tugasnya bertambah yaitu memelihara keamanan daerah taklukan Islam, memimpin ekspedisi-ekspedisi militer, menandatangai perjajian damai, membangun masjid, imam shalat. Amir ini bertanggung jawab kepada pusat pemerintahan yaitu Khalifah di Madinah (Sayuti, 1996: 224).

Dalam Negara Islam kekuasaan otonomi kepala daerah sebagai berikut:

1) Mengumpulkan pajak

2) Mengelola administrasi dan memberi pelayanan kepada rakyat

3) Memelihara keamanan di daerah

4) Menarik Kharaj dan memungut zakat

5) Menegakkan dan menyebarluaskan agama Islam

6) Menjadi imam sholat

Menurut Al-Mawardi dalam buku yang berjudul Ahkam Sulthaniyah, kekuasaan kepala daerah terbagi dalam 2 bagian yaitu: 


\section{Kekuasaan Kepala Daerah Bersifat Umum}

Kepala daerah bersifat umum ini dibagi menjadi 2 bagian yaitu :

a. Kekuasaan kepala daerah atas wilayah tertentu melalui jalan damaiKepala daerah ini memiliki 7 tugas sebagai berikut :

1) Menangani urusan meliter, mengorganisasikan kekuatan mereka di segala aspek, menentukan gaji mereka, kecuali jika gaji sudah ditentukan oleh Khalifah.

2) Menangani urusan-urusan hukum dan mengangkat petugas kharaj dan zakat serta menentukan orang-orang yang berhak menerimanya.

3) Menarik kharaj, memungut zakat

4) Melindungi agama dan memurnikan ajarannya

5) Menegakkan hudud terkait dengan hak-hak Allah maupun hak-hakmanusia

6) Menjadi imam dalam sholat jum "eat dan jama"ah

7) Memberikan fasilitas kemudahan kepada warga dan non warga yang hendak melaksanakan haji.

b. Kekuasaan kepala daerah atas wilayah tertentu melalui paksaan

Yang dimaksud dengan kepala daerah atas wilayah tertentu melalui paksaan ini adalah seorang kepala daerah menguasai wilayah tersebut dengan mengunakan kekuatan senjata kemudian diangkat oleh Khalifah untuk menjadi penguasa di wilayah tersebut kemudian diberi wewenang untuk mengelola serta menatanya. Dengan wewenang yang diberi itu ia memiliki otoritas politik dan kewenangan mengelola wilayah dan memberlakukan aturan-aturan agama atas izin Khalifah.

Kepala daerah ini juga memiliki 7 tugas yaitu :

1) Terlindunginya jabatan Khalifah dalam mewakili tugas kenabian dan menangani urusan-urusan agama supaya segala kewajiban syariat dapat ditegakan

2) Lahirnya sikap taat

3) Terciptanya kebulatan tekad untuk saling tolong menolong

4) Dibenarkannya akad-akad kekuasaan agama supaya aturan-aturankeagamaan dapat dijalankan

5) Terkelolanya dana syariat

6) Ditegakkannya hudud dengan benar

7) Diwajibkan melindungi agama dan menjauhi larangannya (Al-Mawardi 2014: 59)

\section{Kekuasaan Kepala Daerah Bersifat Khusus}

Kepala daerah khusus ini memiliki kewenangannya sebatas mengatur meliter, memimpin rakyat dan melindungi wilayah daerah serta tempat-tempat umum (AlMawardi, 2014 : 65). Kemudian Al-Mawardi juga mengambarkan pemerintahan otonomitelah mencapai tingkat tinggi yang terbagi 2 macam yaitu :

1. Al-Imarah Al-Istila

Yang dimaksud dengan al-imarah al-istila" ini adalah negara-negara bagian yang memiliki kekuasaan yang lebih besar Ada 2 tingkatan bagiannya yaitu :

$a$. Negara bagian biasa. Negara ini memiliki pembagian kekuasaan antara daerah dengan pusat. Dipimpin oleh kepala negara bagian dengan istilah "al-amir".

$b$. Negara bagian istimewa. Negara ini mempunyai hak-hak kekuasaan dalam 
dan luar negara. Dipimpin dengan istilah"al-sultan".

2. Al-Imarah Al-Istikfa

Yang dimaksud dengan al-imarah al-istikfa adalah daerah-daerah otonomi yang memiliki badan-badan kekuasaan lengkap untuk wilayahnya, baik legislatif,eksekutif, kehakiman. Jadi, otonomi kekuasaan kepala daerah dalam itu dibatasi sesuai dengan kondisi dan kewenangan yang diberikan oleh seorang Khalifah.

\section{KESIMPULAN}

Konsep otonomi daerah dalam hukum tata negara islam adalah Al-Imarah Al-Khashah dan Al-Imarah Al-Ammah yang masing-masing memiliki tugas dan fungsi dalam menjalankan kepemerintahan. Selanjutnya, otonomi kekuasan kepala daerah dalam perspektif fiqh siyasah dusturiyah atau hukum tata negara islam sesuai dengan kondisi dan kewenangan yang diberikan oleh seorang khalifah. Khalifah sebagai kepala negara memberikan kewenangan kepada al-amir (kepala daerah) yakni mengumpulkan pajak di daerah, mengelola administrasi daerah dan memberi pelayanan ke rakyat di daerah, memelihara keamanan di daerah, menarik kharaj dan memungut zakat, menegakkan dan menyebar luaskan agama islam di daerah, menjadi imam sholat.

\section{DAFTAR PUSTAKA}

Abdul, A. (2006). Distorsi Sistem Pemberhentian (Impeachment) Kepala Daerah. Yogyakarta: Toga Press.

Abdullah, A. (2016). Konsep Kepemimpinan Dalam Islam. JakartaTimur: Ummul Quran.

Abdullah, A. M. (2015). Perbandingan Antara Fungsi Hisbah dan Lembaga Pengawasan Perekonomian Modren. Jakarta: t.t.

Al-Mawardi. (2019). Ahkam Sulthaniyah Sistem Pemerintahan Khilafah Islam. Jakarta: Qisthi Press.

Al-Usairy, A. (2003). Sejarah Islam Sejak Zaman Nabi Adam Hingga AbadXX. Jakarta: Akbar Media Eka Sarana.

Andi, M. (1999). Otonomi Daerah Dan Kepala Daerah Memasuki AbadXXI. Jakarta: Gaya Media.

Aziz, A. T. A. (t.th). Al-Islam Wa Ad-Dustur

Barama, M. (2016). Jurnal Hukum Unsrat, 22 (5)

Dedi, S. (2007). Perbandingan Figh Siyasah Konsep, Aliran Dan Tokoh-tokoh Politik Islam. Bandung: Pustaka Setia.

Djazuli, (2003). Fikih Siyasah. Jakarta: Prenada Media Group.

Esha, M. I. (2011). Percikan Filsafat Sejarah EPeradaban Islam. Malang: UIN-Maliki Press.

Fachruroji, M. (2008). Jurnal Ilmu Dakwah, 4 (12).

Fatmawati, (2010). Sejarah Peradaban Islam. Batusangkar: Stain Batusangkar Press.

Hanif, N. (2007). Teori dan Praktik Pemerintahan dan Otonomi Daerah. Jakarta: Gusindo.

Hasem, S. (1989). Suksesi Sepeninggalan Rasulullah Awal Perselisihan. Depok: Yafi

HAW, W. (2007). Pemerintahan Daerah. Jakarta. PT Raja Grafindo Persada. 
Husni, M. (2018), Baiat Menurut Mufasir, Fakultas Usuluddin Dan filsafat Universitas Agama Islam Negeri Ar-Raniry Darussalam Banda Aceh.

Ian, W. (1995). Otonomi Daerah: Peluang dan Tantangan. Jakarta: Pustaka Sinar Harapan

Imron, R. (2000). Kekuasaan, Pengkhianatan dan Otoritas Agama: Telaah Kritis Teori AlMawardi Tentang Negara. Yogyakarta: Tiara WacanaYogya.

Jamaluddin, H. (2005). Otonomi Daerah: Antara Cita dan Fakta. Kendari: Fisip Universitas Haluoleo Press.

Muh, R. (2012). Hadits Tarbawi I. Makassar: Alauddin University Press.

Muhammad, I. (2014). Figh Siyasah Kontekstualisasi Doktrin Politik Islam. Jakarta. Prenadamedia Group.

Mujar, S. (2008). Figh Siyasah dan PemikiranPolitik Islam. Jakarta: Erlangga.

Mushaf Al-quran dan terjemahan, diterbitkan Al-Huda edisi tahun 2002.

Rasuki. (2019). Dinamika Konsep Kepemimpinan Dalam Islam: Dari Khilafah, Imamah Sampai Imarah, (07)

Rozali, A. (2007). Pelaksanaan Otonomi Luas Dengan Pemilihan Kepala Daerah Secara Langsung. Jakarta: PT Raja Grasindo

Rulli, N. (2016). Teori Dan Riset Media Siber (Cybermedia). Jakarta: Prenada Media group.

Saiful, I. (2002). Prinsip-prinsip Otonomi Daerah dalam Pemerintahan Negara Islam. Jakarta. Pustaka Panjimas.

Samsu, L. (2017). Al-sultah Al-tasyrieciyyah, Al-sultah Al-tanfiziyyah, Al-sultah Alqada'iyyah. XIII (1)

Sayuti, J. (2009), Prinsip-Prinsip Pemerintahan Dalam Piagam Madinah. Jakarta: Raja Grafindo Persada

Yusuf, Q. (1998). Min Fiqhi al-Daulah Fi al-Islām, terj. Kathur Suhardi. Fiqih Daulah DalamPrespektif al-Quran dan Sunnah. Jakarta: Al-Kausar.

Zainal, A. (2001). Membangun Negara Islam. Cet. I. Yogyakarta: Pustaka Iqra. 